\title{
Spatiotemporal dynamics of submerged macrophyte status and watershed exploitation in a Mediterranean coastal lagoon: Understanding critical factors in ecosystem degradation and restoration
}

\author{
Pasqualini Vanina ${ }^{1,{ }^{*}}$, Derolez Valerie ${ }^{2}$, Garrido Marie ${ }^{1}$, Orsoni Valerie ${ }^{3}$, Baldi Yoann ${ }^{3}$, \\ Etourneau Sabrina ${ }^{4}$, Leoni Vanina ${ }^{4}$, Rébillout Patrick ${ }^{5}$, Laugier Thierry ${ }^{2}$, Souchu Philippe ${ }^{2}$, \\ Malet Nathalie ${ }^{3}$
}

\footnotetext{
${ }^{1}$ UMR SPE CNRS/UMS Stella Mare CNRS, Université de Corse, 20250 Corte, France

${ }^{2}$ UMR MARBEC Ifremer, Laboratoire Environnement Ressources Languedoc- Roussillon (LER/LR), 17 rue Jean Monet, 34200 Sète, France

${ }^{3}$ Ifremer, Laboratoire Environnement Ressources Provence-Azur-Corse (LER/PAC), Station de Bastia, Z.I. Furiani, Immeuble Agostini, 20600 Bastia, France

${ }^{4}$ Réserve Naturelle de l'Etang de Biguglia, Département de la Haute-Corse, Route de l'étang, 20600 Furiani, France

${ }^{5}$ Météo France, Station de Campo dell'Oro, Aéroport d'Ajaccio, 20090 Ajaccio, France

*Corresponding author : Vanina Pasqualini, email address : pasquali@univ-corse.fr
}

\begin{abstract}
:
Increases in the intensity of disturbances in coastal lagoons can lead to shifts in vegetation from aquatic angiosperms to macroalgal or phytoplankton communities. Such abrupt and discontinuous responses are facilitated by instability in the equilibrium controlling the trajectory of the community response. We hypothesized that the shift in macrophyte populations is reversible, and that this reversibility is dependent on changes in the pressures exerted on the watershed and lagoon functioning. Biguglia lagoon (Mediterranean Sea, Corsica) is an interesting case study for the evaluation of long-term coastal lagoon ecosystem functioning and the trajectory of submerged macrophyte responses to disturbances, to facilitate the appropriate restoration of ecosystems. We used historical data for a two hundred-year period to assess changes in human activities on the watershed of the Biguglia lagoon. Macrophyte mapping (from 1970) and monitoring data for dynamics (from 1999) were used to investigate the trajectory of the community response. The changes observed in this watershed included a large number of hydrological developments affecting salinity and resulting in changes in macrophyte distribution. Nutrient inputs over the last 40 years have led to a shift in the aquatic vegetation from predominantly aquatic angiosperm community to macroalgae and phytoplankton in 2007 (dystrophic crisis). Changes in hydrological management and improvements in sewage treatment after 2007 led to a significant increase of aquatic angiosperms over a relatively short period of time (4-5 years), particularly for Ruppia cirrhosa and Stuckenia pectinata. There has been a significant resurgence of Najas marina, due to changes in salinity. The observed community shift suggests that Biguglia lagoon is resilient and that the transition may be reversible. The restored communities closely resemble those present before
\end{abstract}


disturbance. These findings demonstrate the need to understand watershed exploitation and ecosystem variability in lagoon restoration.

Keywords: Coastal lagoons, Human pressures, Long-term changes, Submerged macrophytes, Community shifts 


\section{Introduction}

(n)

Coastal lagoons provide essential ecosystem services and have a high economic potential (Kjerfve, 1994). They are intrinsically unstable due to their transitional location between continental and marine biota, morphodynamics and environmental factors, potentially resulting in profound spatiotemporal changes in physical, chemical and biological conditions (Barnes, 1980; Bird, 1994; Day et al., 2000). Coastal lagoons have been among the most disturbed coastal ecosystems worldwide since the mid-20 ${ }^{\text {th }}$ century (De Jonge et al., 2002). Jennerjahn and Mitchell (2013) identified three categories of major hazards to ecosystems: human activities, climate change and extreme events. For example, increases in population density along coastlines, changes in watershed activities, hydrological regulation and eutrophication can strongly affect the physicochemical conditions in coastal lagoons (Nixon, 1995; Cloern, 2001; Lloret et al., 2008; Downing, 2014). Nevertheless, estuaries subject to anthropogenic and natural stresses often have similar characteristics, making it difficult to distinguish between them and, thus, to determine the nature of the anthropogenic stress (Jennerjahn and Mitchell, 2013). Increases in disturbance intensity and abrupt changes in disturbances can lead to persistent radical changes, resulting in the dominance of one or a few species (Folke et al., 2004; Cloern and Jassby, 2012). Folke et al. (2010) characterized the dynamics of complex social-ecological systems by studying three aspects: resilience, adaptability and transformability. Changes in system dynamics are referred to as regime shifts, and such shifts may be reversible or irreversible (Scheffer et al., 2001). Abrupt and discontinuous responses are facilitated by instability of the equilibrium controlling the trajectory of the community response (Collie et al., 2004; Suding et al., 2004; Schröder et al., 2005). Elliot et al. (2007) showed that disturbances affected both the structure and functioning of the ecosystem. 
Submerged macrophytes are essential coastal lagoon species, with important structural and ecological functions (Sfriso et al., 2001, 2003; Duarte et al., 2002; Marzano et al., 2003; Garrido et al., 2013). They can be used as bioindicators of ecosystem health, because they display community-level responses to nutrients in the water, in terms of species diversity, structure and cover density (Pasqualini et al., 2006). Eutrophication can lead to vegetation shifts, described as a transition between alternative states, from pristine slow-growing benthic plants (aquatic angiosperms) to rapidly growing ephemeral plants (macroalgal or phytoplankton communities; Duarte, 1995; Viaroli et al., 1996; Valiela et al., 1997; Schramm, 1999; Dahlgren and Kautsky, 2004; Orfanidis et al., 2008a, 2008b; Viaroli et al., 2008). Under the low-nutrient and clear-water conditions of the pristine oligotrophic state, the latesuccessional angiosperms Ruppia and Zostera spp. become dominant (Pergent-Martini et al., 2005; Pergent et al., 2006). By contrast, opportunistic seaweeds, such as Gracilaria, Ulva and Cladophora spp., together with cyanobacteria and picophytoplankton, are indicators of the degraded eutrophic state, in which nutrient levels are high (Bec et al., 2011). The first conceptual model was proposed by Nienhuis (1992), and was based on a phase succession (aquatic angiosperms > aquatic angiosperms+epiphytes > macroalgae+phytoplankton). Schramm (1999) developed a model based on a similar successional representation (perennial benthic macrophytes > macrophytes+fast growing epiphytes $>$ free floating macroalgae+phytoplankton > phytoplankton) adding a more detailed explanation of possible causes and trends. Viaroli et al. (2008) and Fong and Kennison (2010) also included cyanobacteria in their model. The primary causes of shifts and succession in the macrophyte community are nutrient loading (mostly nitrogen and phosphorus from watershed activities; Valiela et al., 1997; Dahlgren and Kautsky, 2004), changes in coastal hydrology and interactions between these factors. Primary producer succession may be strongly favored or prevented by water residence time (Flindt et al., 1997), as described by Valiela et al. (1997), 
Hauxwell and Valiela (2004), Dahlgreen and Kautsky (2004), where the effects of nutrients are related to hydrodynamics.

An understanding of the mechanisms controlling the capacity of an ecosystem to recover after disturbances and of the ways in which human activities can alter this capacity is crucial to the success of ecosystem restoration (Folke et al., 2004). A pronounced degradation of trophic state and decrease in macroalgal biomass has been recorded in Venice lagoon, together with a progressive expansion of seagrass meadows (Facca et al., 2014). Excess nutrients are thought to induce the shift between the two alternative states (Viaroli et al., 2008), both of which are thought to be resilient, due to the existence of feedback mechanisms (Carpenter et al., 2001). According to Clewell and Aronson (2007), it is not possible to separate humans and ecosystems entirely, and the satisfactory restoration of ecosystems is therefore dependent on attention being paid to the interactions between humans and the natural environment. A retrospective view of human activities is essential, to improve understanding, for the restoration of processes (Fukami and Wardle, 2005), particularly in unstable lagoon environments. One useful approach to understanding the long-term ecological dynamics of coastal lagoons is based on analyses of historical data concerning watershed activities, including changes to land use/cover and hydrological regulations in particular (Kemp et al., 2005; Steyaert et al., 2007). An understanding of the resilience of coastal lagoons and their capacity to recover efficiently after exposure to human stressors requires spatial and temporal data for submerged macrophytes (aquatic angiosperms and macroalgae), phytoplankton and environmental parameters reflecting water quality.

In this study, we analyzed the overall functioning of a coastal lagoon ecosystem, to determine the trajectory of the vegetation community response to the major human pressures, with a view to optimizing the restoration of the ecosystem. We focused on two particular objectives: (i) characterizing the functioning of the coastal lagoon in the medium and long 
term, as a function of pressures relating to watershed activities and local meteorological and

125 hydrological conditions and (ii) following the spatiotemporal dynamics of macrophyte populations in response to recent anthropogenic pressures. In this context, Biguglia lagoon (Mediterranean Sea, Corsica, France; Fig.1) is an interesting case study, because data concerning anthropogenic pressures and macrophyte populations are available for a recent 15year period. We hypothesized that the succession or shift in macrophyte populations is reversible, and that this reversibility depends on changes in the pressures exerted on the watershed and lagoon functioning. The key questions to be addressed are: (i) Are coastal lagoons resilient to changes in these pressures? (ii) If they are, then how similar are the pristine and restored communities? (iii) If they are not, what is the disturbance threshold beyond which they cannot recover?

\section{Material and methods}

\subsection{Study site}

Biguglia lagoon $\left(42^{\circ} 36^{\prime} \mathrm{N}\right.$; $\left.9^{\circ} 28^{\prime} \mathrm{E}\right)$ is a confined, shallow, brackish coastal lagoon (maximum depth: $1.8 \mathrm{~m}$ ) covering $14.5 \mathrm{~km}^{2}$ that is separated from the Mediterranean Sea by a long sandy beach $(11 \mathrm{~km}$; Fig. 1). The lagoon is linked to the Mediterranean Sea through a long $(1.5 \mathrm{~km})$, narrow, shallow natural channel to the north (Fig. 1). Marine water inputs are limited (Mouillot et al., 2000) because the sea channel tends to close (due to the accumulation of sand), and human intervention is sometimes required to open it again. Biguglia lagoon receives freshwater from the rivers draining its watershed $\left(180 \mathrm{~km}^{2}\right)$, mostly in the northwestern part, from the River Golo (through an artificial channel: the Fossone canal) and from pumping stations draining the agricultural plain in the southern part of the watershed, sewage 
149

150

151

152

153

154

155 1721800 to 1999 , population data collected at intervals of about five years

plants and rainfall (Fig. 1; Frisoni and Dutrieux, 1992). Freshwater inputs dominate the water budget $\left(\approx 90 \mathrm{Mm}^{3}\right.$ per year, for a total lagoon volume of $\left.10.2 \mathrm{Mm}^{3}\right)$ and lagoon renewal is rapid (< two months; Mouillot et al., 2000). This confined ecosystem has increasingly been disturbed by eutrophication associated with an intensification of agriculture and an increase in the density of urban settlements in the watershed, together with additional pressure due to the presence of tourists in the area in the summer (Frisoni and Dutrieux, 1992; Orsoni et al., 2001; Andral et al., 2007; Département de la Haute-Corse, 2012). Nutrient concentrations in this lagoon are higher than in most other Mediterranean lagoons (e.g. total nitrogen, ammonium in 1998; Orsoni et al., 2001; Souchu et al., 2010), due to the existence of fewer opportunities for dilution with seawater. High levels of silt and organic matter accumulation have been recorded across the entire lagoon (Orsoni et al., 2001). This lagoon has a Mediterranean climate, with large, unpredictable fluctuations in rainfall between years (Chauvelon et al., 2003). Biguglia lagoon was included in the RAMSAR list of wetlands of international importance in 1991, and has been classified as a nature reserve since 1994. It is managed by a local government agency (Département de la Haute-Corse, 2013). The lagoon is mostly used for professional fishing.

\subsection{Environmental data}

We used historical documents and maps to analyze the functioning of Biguglia lagoon and to identify the major anthropogenic pressures acting on the watershed in the long term (from the $18^{\text {th }}$ century). Human population history between the early $19^{\text {th }}$ century and the present day was assessed for all human settlements, based on the number of inhabitants per town (four towns in the watershed). The following population data were available: (i) from

173 (http://cassini.ehess.fr/cassini/fr/html/6_index.htm) and (ii) French National Statistics and 
174 Economic Studies Agency (INSEE) data for 1999 to 2011, collected at intervals of seven to

175 nine years. We used two maps to analyze historical land cover in the watershed. The first map

176 of Corsica, Plan Terrier, was ordered in 1774 by Louis XV of France, to provide an inventory

177 of the natural resources of the island after its acquisition (Caratini, 1995). This map is precise,

178 at a scale of 1:10,000 (Source: Archives départementales de Corse du Sud; Albitreccia, 1942),

179 and it was georeferenced with ArcGis version 10.0 (ESRI®). Land-cover patches were

180 represented as polygons on a schematic topographic background. The polygons were redrawn

181 in vector format, by tracing the lines of the scanned and georeferenced map. The CORINE

182 land-cover program established a precise land-cover map of the study site for 2006

183 (http://www.statistiques.developpement-durable.gouv.fr/donnees-

184 ligne/li/1825/1097/occupation-sols-corine-land-cover.html). For all these numerical vector

185 maps, data were georeferenced with Lambert 93 coordinates, and we considered three generic

186 land-cover types, as defined by the CORINE land cover program: forests and shrublands,

187 farmland, and urban areas. The surface areas corresponding to these three generic land-cover 188 types were calculated for the two maps (1774 and 2006). An additional survey was conducted 189 in this area by the French fiscal services (Source: Archives départementales de Haute-Corse;

190 Corvol, 1999). This survey provided information about the composition of the landscape for 191 the year 1879 , but in a non-spatial format. We used these data to obtain an intermediate 192 update of landscape composition.

More detailed information about local meteorological and hydrological functioning 194 began to become available from the $19^{\text {th }}$ century onwards. Météo-France ${ }^{\circledR}$ has recorded 195 annual spring and summer cumulative rainfall levels since 1948 at Bastia Airport, which is 196 located close to the lagoon. Mean summer lagoon salinity data for the northern and southern 197 basins were obtained from records published since 1930 (1930; 1978; 1982; 1983; 1990; 
Burelli et al., 1979; Frisoni and Dutrieux, 1992; Orsoni et al., 2001; IFREMER data) and from recordings made during this study (from 1999 to 2014).

We used 10 parameters for the short-term analysis of water quality: salinity (PSU: practical salinity units), water temperature $\left({ }^{\circ} \mathrm{C}\right)$, turbidity (NTU: nephelometric turbidity units), dissolved oxygen $\left(\mathrm{O}_{2}, \%\right)$, nitrate $\left(\mathrm{NO}_{3}, \mu \mathrm{M}\right)$, ammonium $\left(\mathrm{NH}_{4}, \mu \mathrm{M}\right)$, nitrite $\left(\mathrm{NO}_{2}\right.$, $\mu \mathrm{M}$ ), dissolved inorganic nitrogen (DIN=NO$+\mathrm{NH}_{4}+\mathrm{NO}_{2}, \mu \mathrm{M}$ ), phosphate (DIP, $\mu \mathrm{M}$ ), total nitrogen $(\mathrm{TN}, \mu \mathrm{M})$, total phosphorus $(\mathrm{TP}, \mu \mathrm{M})$ and chlorophyll $a$ (chl $\left.a ; \mu \mathrm{g} . \mathrm{L}^{-1}\right)$ concentrations. The database developed by the Lagoon Monitoring Network (Réseau de Suivi Lagunaire) can be used to assess the eutrophication status of lagoons (Souchu et al., 2010). Sampling was carried once monthly during the summer period (June, July and August) from 1999 to 2014 (but not in 2000, 2001 and 2005, due to technical problems), at two stations in the lagoon (the northern and southern basins; Fig. 1). Water was sampled principally during the summer period, corresponding to the peak of primary production in Mediterranean lagoons (Souchu et al., 2010; Bec et al., 2011). We avoided the collection of samples during periods of sediment resuspension, by not sampling for three days after any period in which wind speed exceeded $25 \mathrm{~m} . \mathrm{s}^{-1}$. For each sampling station, subsurface salinity, temperature, turbidity and dissolved oxygen measurements were performed in situ with a multiparameter water quality probe (YSI Environmental Monitoring Systems, 6600 V2-2). At each station, we collected subsamples of water $(80 \mathrm{~mL})$, which were stored in polyethylene bottles at $20^{\circ} \mathrm{C}$ until nutrient analysis. DIN and DIP concentrations were determined by manual colorimetric methods, as described by Aminot and Kérouel (2004). Total nitrogen and total phosphorus concentrations were determined by wet oxidation and automated colorimetry (Raimbault et al., 1999). For chlorophyll $a$ determinations, we filtered $50 \mathrm{~mL}$ of a water sample through Whatman GF/F membranes $(0.7 \mu \mathrm{m}$ pores $)$ under vacuum $(<10 \mathrm{~cm} \mathrm{Hg})$. The filters were then placed in glass tubes and stored at $-20^{\circ} \mathrm{C}$. Filters were ground in acetone 
$223(90 \%)$ and incubated for $24 \mathrm{~h}$ in the dark at $4^{\circ} \mathrm{C}$. Pigment levels were measured by 224 spectrofluorimetry (Neveux and Lantoine, 1993). Concentrations are expressed in $\mu g . \mathrm{L}^{-1}$ 225 (precision $\pm 5 \%$ ).

\subsection{Macrophyte mapping and monitoring of dynamics}

Earlier maps of the main macrophytes and bottom types in Biguglia lagoon were available for studies of the change in macrophyte distribution. The first two maps were produced by De Casabianca et al. (1973) and Frisoni and Dutrieux (1992), at a scale of 1:20,000, and were based mostly on in situ observations. Each map was scanned and georeferenced with ArcGis version 10.0 (ESRI®). The areas of aquatic angiosperms and macroalgae were redrawn in vector format, by tracing polygons on the scanned and

234 georeferenced maps. Pasqualini et al. (2006) made accurate maps of the main macrophytes and bottom types in Biguglia lagoon in 1999. Aerial photographs were used for image 236 processing, as described by Pasqualini et al. (1997). The resulting map was then 237 georeferenced with Lambert 93 coordinates and converted to vector format in a GIS database. 238 The current distribution of macrophytes and other bottom types within Biguglia lagoon was 239 determined by mapping with the same method (Pasqualini et al., 1997; Garrido et al., 2013), 240 from color aerial photographs (May 2010, 1:10,000 scale; International Air Photo®) and field 241 observations (Spring-Summer 2010, 35 transects distributed throughout the lagoon and 242 recorded by differential GPS). This technique combines a high level of precision and rapid 243 processing (Pasqualini et al., 1997; 2001). Image processing (ENVI software) led to the 244 identification of six main bottom types: Najas marina L., Ruppia cirrhosa (Petagna) Grande and/or Stuckenia pectinata (L.) Börner (formerly known as Potamogeton pectinatus), mixed

246 aquatic angiosperms (Najas marina, Ruppia cirrhosa, and/or Stuckenia pectinata), silt, 247 macroalgae, Posidonia oceanica (Linnaeus) Delile litter and sand. Three images, 
corresponding to the three different layers (i.e., red, green and blue), were obtained from

249 aerial photographs. The dynamics of each layer was adjusted by enhancing image contrast

250 (linear contrast enhancement) to improve precision and clarity. Principal component analysis

251 (PCA) was carried out on the green and blue layers. A supervised classification (by the

252 generalized hypercube method) was applied to color composition. The polygons were then

253 positioned on the basis of field observations in situ. The final images were occasionally

254 corrected on the basis of the field data. All the maps (1972/1973, 1991, 1999 and 2010) were

255 georeferenced with Lambert 93 coordinates and converted to a vector format in a GIS 256 database.

Macrophyte dynamics were monitored from 1999 onwards, to assess the 258 eutrophication status of Biguglia lagoon according to the Lagoon Monitoring Network 259 method (Réseau de Suivi Lagunaire; Souchu et al., 2010; Ferreira et al., 2011), which meets 260 the requirements of the Water Framework Directive (2000/60/CE). Macrophyte community 261 coverage was estimated in 1999, 2003, 2009, 2012 and 2014, at 15 stations in Biguglia lagoon 262 (Fig. 1), in June, during the period of maximal macrophyte growth before the summer 263 senescence period. At each station, macrophyte coverage was estimated in situ on areas of 264 about $120 \mathrm{~m}^{2}$ corresponding to a circle with a radius of about $6 \mathrm{~m}$. This surface area was 265 considered suitable for the detection of all the taxa present in the selected areas (Ferreira et 266 al., 2011). The total vegetation cover and the percentage cover for each aquatic angiosperm 267 and macroalgal species were determined by eye, and a representative sample was 268 systematically collected for the validation of species-level identifications in the laboratory.

\subsection{Statistical analysis}

271 We used XLStat ${ }^{\circledR}$ V2011 5.01 statistical software for comparisons. We used 272 nonparametric Kruskal-Wallis one-way analysis of variance on ranks to evaluate the 
273 significance of differences in environmental data between stations and between sampling 274 years. The Conover-Iman test was then used to highlight differences between years. This test 275 calculates stochastic dominance and reports results for multiple pairwise comparisons. We 276 used nonparametric Spearman's rank correlation ( $\rho$ ) analysis to identify potential 277 relationships between environmental variables. Values of $p<0.05$ were considered significant. 278 Principal component analysis (PCA) was carried out with the FactoMineR package of R 279 software to highlight potential links between abiotic and biotic parameters, and similarities 280 between sampling stations and years of sampling. This multivariate analysis method is 281 particularly suitable for ecological data, as it makes no assumptions about the structure 282 between samples or about the normality of the data distribution. Biotic and abiotic data 283 collected over the same sampling period were included in the PCA analysis: June 1999, June 284 2003, June 2009, June 2012 and June 2014. Only variables without missing values and with 285 low Spearman correlation coefficients were included as active variables in the PCA, to prevent bias. Meteorological variables (rainfall levels and water temperature) were added as illustrative variables. For comparison with the abiotic data collected at the two water sampling stations ( $\mathrm{N}$ and $\mathrm{S}$; Fig. 1), percentage coverage data for macroalgae, and for the macrophytes Ruppia cirrhosa and of Stuckenia pectinata were averaged for the stations of the lagoon.

\section{Results}

\subsection{Environmental data}

The number of inhabitants of the Biguglia watershed remained relatively small and constant from the early $19^{\text {th }}$ century to the mid- $20^{\text {th }}$ century (about 2,000 inhabitants; Table 1 ).

297 However, whereas farmland accounted for less than $40 \%$ of the watershed in the late of $18^{\text {th }}$ 
298 century, it accounted for more than $80 \%$ at the end of the $19^{\text {th }}$ century (Table 1 ). The number 299 of inhabitants has increased considerably since 1970 (reaching about 25,000 in 2011), and this 300 increase was associated with an increase in the size of urban areas and a decrease in the areas 301 covered by farmland or forests and shrublands (Table 1).

Rainfall in the Biguglia watershed has varied considerably between years since 1948.

303 Annual rainfall ranged from $330 \mathrm{~mm}$ in 1952 to $1371 \mathrm{~mm}$ in 2008, with a mean value of 765 $\mathrm{mm}(\mathrm{CV}=26.8 \%)$. Rainfall levels were significantly higher in the spring and fall than in the winter and summer (Spearman, $\mathrm{p}<0.05)$. Mean summer salinity data were available from 1930 onwards and ranged from 11.0 PSU in 2014 to 27.2 PSU in 2012 for the northern basin, and from 7.3 PSU in 2014 to 14.5 PSU in 2012 in the southern basin. Mean summer salinity differed between the northern and southern basins (Spearman, $\mathrm{p}<0.05$ ). Salinity was significantly correlated with summer rainfall levels (Spearman, $\mathrm{p}<0.05$ ).

Between 1999 and 2014, summer parameters displayed interannual variability at Biguglia lagoon (Fig. 2; Table 2). In the northern basin, salinity, turbidity and ammonium concentration varied from year to year (Fig. 2; Table 2). In the southern basin, interannual variation was observed for a larger number of parameters, including salinity, turbidity, nitrates, ammonium, total nitrogen, total phosphorus and chlorophyll $a$ concentrations (Fig. 2; Table 2). Significant differences were observed for many parameters in 2007 (Fig. 2; Table 2). In the summer of 2007, Biguglia lagoon suffered a dystrophic crisis associated with the massive development of a potentially toxic cyanobacterium, Anabaenopsis circularis (G.S. West) Woloszynnska \& V. Miller (IFREMER data). In the other years, significant differences were observed for only one or two parameters, which were influenced by very large peaks (e.g. peak in 2014 for nitrates in the southern basin; Fig. 2; Table 2).

\subsection{Macrophyte mapping and monitoring of dynamics}


324 predominance of aquatic angiosperms ( $84 \%$ of the total lagoon area; Table 3$)$. Four aquatic angiosperms were present in Biguglia lagoon: Zostera noltei Hornemann close to the sea channel in the north, Ruppia cirrhosa and Stuckenia pectinata throughout the lagoon and Najas marina in the southern basin. Ulva sp. was also present, but with a low prevalence. Conversely, in 1991 (Frisoni and Dutrieux, 1992), Ulva sp. occupied 65\% of the total area of the lagoon, with aquatic angiosperms covering only 51\% (Table 3). In 1991, two aquatic angiosperm species were encountered (Ruppia maritima Linnaeus and Stuckenia pectinata). Aquatic angiosperm levels were lowest in 1999 (Pasqualini et al., 2006), when these plants covered only $13 \%$ of the total area, whereas Ulva sp. and Gracilaria sp. covered $7 \%$ of the lagoon (Table 3). Four aquatic angiosperms were present in Biguglia lagoon: Zostera noltei 334 close to the sea channel, Ruppia cirrhosa (95\% of the aquatic angiosperms present) and Ruppia maritima throughout the lagoon, and Stuckenia pectinata, mostly in the south-western part of the lagoon. Najas marina was not observed in 1999. In 2010, analysis of the Biguglia lagoon map revealed a predominance of aquatic angiosperms (62\% of the total area; Table 3$)$, 338 mostly in the southern basin for Najas marina (17\%), throughout the lagoon for Ruppia 339 cirrhosa and/or Stuckenia pectinata (40\%), and in the southern basin for mixed aquatic angiosperms (5\%; Stuckenia pectinata and Najas marina; Fig. 3). Macroalgal formations were 341 observed mostly in the northern basin (14\%), in the form of tufts within the Ruppia cirrhosa 342 meadows (Fig. 3; Table 3). Posidonia oceanica, an exclusively marine species, was found 343 only as litter, close to the points of communication with the sea and partly blocking the 344 connecting channel (Fig. 3). The monitoring of macrophyte dynamics between 1999 and 2014 showed interannual 346 variability in aquatic angiosperm coverage (Fig. 4). Essentially, two species were encountered 347 (Ruppia cirrhosa and Stuckenia pectinata), with Ruppia cirrhosa predominating in the 
northern basin (notably in 2014) and Stuckenia pectinata predominating in the southern basin

349 (notably in 2012). Aquatic angiosperms were less prevalent in Biguglia lagoon in 1999, 2003

350 and 2009. Macroalgal community diversity and coverage also varied between years (Fig. 4).

351 Coverage was highest in 1999 and 2003, for both basins, whereas only one macroalga (Ulva 352 instestinalis Linnaeus) was observed in 2009, with low coverage. Gracilaria dura (C.Agardh)

353 J.Agardh was well represented, particularly in the southern basin, in 1999 and 2003. In these

354 years, Ulvaria obscura (Kützing) P.Gayral ex C.Bliding (formerly known as Monostroma 355 obscurum), Ulva rigida C.Agardh, Gracilaria gracilis (Stackhouse) M.Steentoft, L.M.Irvine \& W.F.Farnham and Neosiphonia sertularioides (Grateloup) K.W.Nam \& P.J.Kang (formerly known as Polysiphonia sertularioides) were also detected, particularly in the northern basin (Fig. 4). Intermediate results were obtained for 2012 and 2014, with a predominance of macroalgae in the northern basin in 2014 (Fig. 4). Gracilaria gracilis was present in 2012, notably in the northern basin, whereas Gracilaria bursa-pastoris (S.G.Gmelin) P.C.Silva was found throughout the lagoon in 2014. In these years, Neosiphonia sertularioides, Chaetomorpha aerea (Dillwyn) Kützing and Cladophora vagabunda (Linnaeus) Hoek were also sampled (Fig. 4)

\subsection{Relationships between environmental and macrophyte data}

The PCA analysis was performed on 9 active variables (chlorophyll $a$, DIP, DIN, turbidity, dissolved oxygen, salinity, cover percentages for macroalgae, Ruppia cirrhosa and

Stuckenia pectinata). $\mathrm{NH}_{4}, \mathrm{NO}_{2}$ and $\mathrm{NO}_{3}$ were considered to be illustrative variables because 369 they were highly correlated with DIN (Spearman, $\mathrm{p}<0.5 ; \mathrm{r}=0.81,0.77,0.77$, respectively). TN and TP were not retained in the analysis because of missing values in 1999 and 2009, and

371 because these variables were significantly correlated with chlorophyll $a$ levels (Spearman, $372 \mathrm{p}<0.5 ; \mathrm{r}=0.61,0.50$, respectively). The first two principal components (PC) accounted for 
$57.58 \%$ of the total variance (PC1: $23.76 \%, \mathrm{PC} 2: 33.82 \%$; Fig. 5a). Turbidity and chlorophyll $a$ concentration contributed to the construction of $\mathrm{PC} 1$ with strong negative correlations (loadings: $-0.91,-0.87$, respectively; Fig. 5a), probably largely due to the production of phytoplankton. By contrast, a positive correlation was observed for salinity (loading: 0.70), but this variable made a smaller contribution to PC2 (Fig. 5a). PC2 was positively correlated with DIP and negatively correlated with Stuckenia pectinata coverage (loadings: 0.70 and 0.67 , respectively).

The graphical locations of stations centroid in the plane formed by the PC1-PC2 axes highlights the opposition between the two basins along the first axis, with higher eutrophication and lower salinity levels for the southern basin (Fig. 5b). PC2 was driven by changes in DIP and Stuckenia pectinata coverage levels over time in the southern basin. Evolution trajectory of the southern basin in PC1-PC2 axes plane highlighted macroalgae coverage increasing from June 1999 to June 2003. In June 2009, macroalgal coverage and DIP had decreased and chlorophyll $a$ levels had increased, these changes being associated with high levels of summer rainfall and low salinity. Stuckenia pectinata coverage increased between 2009 and 2012, but subsequently decreased in June 2014, when phytoplankton biomass increased. Data for the northern basin made a smaller contribution to PC1 and PC2 than data for the southern basin.

\section{Discussion}

An understanding of the patterns of change in anthropogenic pressures that have occurred in the past can help us to determine the most appropriate management measures for the restoration of Mediterranean lagoons. In this context, the historical data available for the 
watershed of the Biguglia lagoon provide useful information to improve our understanding of the patterns of change in the hydrological and ecological functioning of lagoons. Two key factors have had a major effect on the benthic vegetation succession/shift of the Biguglia lagoon: salinity and nutrient enrichment.

There is currently a steep salinity gradient between the northern and southern basins of the lagoon. This gradient may change considerably with the configuration of the lagoon, the hydrological watershed, and meteorological conditions (rainfall). The configuration of the lagoon at the end of the $18^{\text {th }}$ century was identical to that today, with a channel communicating with the sea at the north of the lagoon (Fig. 1; Letteron, 1923; Plan Terrier map of 1774). However, drainage measures have been implemented since the end of the $18^{\text {th }}$ century, with the establishment of canals to favor cultivation of the watershed, and periodic interventions to open the lagoon to the sea, to ensure efficient emptying of the lagoon (Jaujou, 1954). Agricultural areas occupied less than $40 \%$ of the watershed in 1774 , and the population was small. The Fossone Canal connecting the River Golo and the south of the lagoon (Fig. 1; $4 \mathrm{~km}$ long) was created at about this time. A new remediation program was initiated at the end of the $19^{\text {th }}$ century, with the establishment of a drainage canal around the lagoon to drain the adjacent marshes, and the installation of five pumping stations (Fig. 1; Département de la Haute-Corse, 2012). Agricultural land occupied more than $80 \%$ of the watershed, but the population remained small. The watershed gradually became more suitable for human settlement, and a significant increase in the number of inhabitants was observed from the 1970s onwards (suburban extension of Bastia and changes in land use in the Mediterranean mountains; San Roman Sanz et al., 2013). The current network of drainage canals and pumping stations does not satisfy agricultural needs and clearly affects lagoon salinity. Freshwater inputs currently dominate the water budget $\left(\approx 90 \mathrm{Mm}^{3}\right.$ for a total lagoon volume of $10.2 \mathrm{Mm}^{3}$; Mouillot et al., 2000). Biguglia lagoon has salinity levels corresponding to 
423 polyhaline and mesohaline ecosystems (Battaglia, 1959). Salinity levels vary from year to 424 year and are dependent on meteorological conditions (spring and fall rainfall), which exert 425 tight control over the in situ environmental conditions, particularly in Mediterranean climates 426 (Tagliapietra and Ghirardini, 2006). Nevertheless, the salinity of the Biguglia lagoon 427 decreased steadily from 1999 to 2011, in both the northern and southern basins. The rapid 428 increase in salinity observed in 2012 reflected the mechanical opening of the current channel 429 of communication with the sea (significant salt water input) by the managers of the natural reserve.

The quality of freshwater inputs has declined, and this process has undoubtedly been exacerbated by a sewerage system that has not yet been adapted to deal with the increase in 433 the number of inhabitants in the watershed (Département de la Haute-Corse, 2012). Biguglia 434 lagoon remains a major site of agricultural and urban activities, favoring large nitrogen inputs. 435 The total and dissolved inorganic nitrogen concentrations obtained during the summer months in this study are higher than those reported for other Mediterranean lagoons, such as Sacca di 437 Goro in Italy (Viaroli et al., 2006; Giorgani et al., 2009), or other French lagoons (Souchu et 438 al., 2010). Conversely, summer nitrate concentrations in Biguglia lagoon are much lower than 439 those measured annually in some estuaries, such as the Ebro delta (nitrates $>0.2 \mathrm{mM}$; Vidal et al., 1997). The available data for nutrient levels in other seasons indicate that ammonium and 441 nitrate concentrations can be high in Biguglia lagoon ( $>80 \mu \mathrm{M}$ for ammonium and $>20 \mu \mathrm{M}$ 442 for nitrate; Orsoni et al., 2001; Garrido et al., 2016). Some of the phosphorus concentrations 443 obtained for this lagoon during the summer months were higher than those reported for other 444 French lagoons (Souchu et al., 2010), and exceeded the annual concentrations measured in 445 some coastal embayments (Lie et al., 2011; Saeck et al., 2013). The northern basin of 446 Biguglia lagoon may be considered mesotrophic, and the southern basin eutrophic (Souchu et 447 al., 2010). The inorganic nutrients in the waters of lagoons subject to anthropogenic pressure 
448 reflect the cumulative effects of inputs from rivers and sewage, uptake, grazing, sediment449 water fluxes, recycling processes, and stock (Fisher et al., 1992). Total nutrient-based 450 approaches for predicting algal (phytoplankton and macroalgae) biomass are very efficient in 451 lagoons (Souchu et al., 2010). Typically, in mesotrophic to hypertrophic lagoons with a high 452 stock of P-rich sediment, shallow water and resuspension, high summer temperatures and 453 anoxic events, the concentration of $\mathrm{P}$ in the water column results partly from sediment fluxes 454 (De Wit et al., 2001; Thouzeau et al., 2007). However, extreme events, such as dystrophic crises, or instantaneous events (peak of ammonium concentration and recent increases in nitrate concentration) may occur. Variations of salinity and nutrient input are known to affect the growth of macroalgae and aquatic angiosperms (Cloern, 2001; De Jonge et al., 2002; Charpentier et al., 2005; 459 Orfanidis et al., 2008b). Our sampling strategy focused on the summer period and did not, therefore, highlight seasonal changes in macrophyte levels, but the data obtained made it possible to compare years, in conditions of maximal primary production. The variability of the dataset resulted mostly from variations of chlorophyll $a$ and turbidity. The relationship between turbidity/chlorophyll $a$ and salinity/summer rainfall indicated that the observed 464 turbidity resulted principally from phytoplankton production that seemed to be linked to freshwater inputs. It also highlights the independence of these 4 variables and DIP and $\mathrm{NH}_{4}$, due to instantaneous peaks of dissolved nutrient concentrations in the southern basin in 1999 and 2003. Finally, our analysis revealed no clear relationship between the water column and macrophyte data, except for the negative correlation between chlorophyll $a$ and macroalgae

469 levels, due to the dystrophic crisis in 2007, resulting in a shift in the vegetation from macroalgae to phytoplankton between 2003 and 2009. Additional correlation analyses

471 performed separately for the two basins of the lagoon revealed significant relationships 472 between Ruppia cirrhosa and salinity and between Stuckenia pectinata and $\mathrm{NO}_{2}($ Spearman, 
$473 \mathrm{r}=-0.80$ and 0.67 , respectively) in the northern basin, and between Stuckenia pectinata and 474 spring rainfall and temperature in the southern basin (Spearman, $r=0.97$ ). All these results 475 suggest that turbidity and chlorophyll $a$ levels have a larger effect on macroalgae than on 476 Ruppia cirrhosa and Stuckenia pectinata, which seem to be more strongly influenced by 477 abiotic parameters.

Three periods of benthic vegetation succession have been observed in Biguglia lagoon: from 1970 to 2007, the year 2007 and from 2007 to the present (Fig. 6). Between 1970 and 2007, changes were observed in the abundance of aquatic angiosperm species (Fig. 6). Zostera noltei was present throughout the study period, but only in the northern basin of the lagoon, close to the sea channel. This euryhaline species thrives in almost all salinity conditions, from near freshwater to a salinity of more than 30 , including situations in which salinity changes rapidly (Hemminga and Duarte, 2000; Charpentier et al., 2005). Conversely, Ruppia cirrhosa was found throughout the lagoon, but the area covered by this species decreased considerably over the 1970-2007 period. Ruppia is a cosmopolitan genus, tolerant to salinity fluctuations, and is typically found in coastal lagoons (Verhoeven, 1979; 488 Menéndez, 2002). In Europe, Ruppia cirrhosa grows in water with salinities of 3 to 100 PSU 489 (Verhoeven, 1979). This remarkable tolerance to salinity variations makes Ruppia cirrhosa a good bioindicator for coastal lagoons, because salinity fluctuations are unlikely to be responsible for major changes and discontinuities in the community. Stuckenia pectinata was

492 found only in the center and south of the lagoon, and the area occupied by this species 493 decreased from 1970 to 2007. This species is a perennial annual submerged pondweed with 494 large numbers of long narrow leaves. It grows on sediments in still or flowing eutrophic fresh 495 water, lakes, rivers and in brackish lagoons (Menéndez and Comin, 1989). Najas marina was present in the 1970s but disappeared from the lagoon in the 2000s, undoubtedly due to 497 changes in salinity. Najas marina is widespread at the freshwater to slightly oligohaline end 
of the salinity gradient, in ponds, lakes, coastal and inland marshes, although it is generally found at lower abundances in these environments (Handley and Davy, 2002). In addition to the significant impact of nitrogen inputs in Biguglia lagoon, the north-south salinity gradient has also clearly affected the distribution of aquatic angiosperms. The northern basin is consistently saltier than the southern basin, due to the input of salt water via the communication channel with the sea (short residence time; mostly Zostera noltei and Ruppia cirrhosa). The southern basin is less salty and more confined, with a longer water residence time (mostly Ruppia cirrhosa, Stuckenia pectinata and Najas marina).

By contrast to aquatic angiosperms, the populations of macroalgae increased considerably during the 1970-2007 period (Fig. 6). Under conditions of nutrient excess and high turbidity, there is a shift in species composition from aquatic angiosperms to the dominance of opportunistic macroalgae (Schramm, 1999; Viaroli et al., 2008). This situation reflects the efficiency of nutrient assimilation by these opportunistic macroalgae (Duarte, 1995). Opportunistic macroalgae have lower light requirements for growth than rooted aquatic angiosperms (Hemminga and Duarte, 2000), and the displacement of aquatic angiosperms seems to be induced principally by nitrogen, rather than by phosphorus (Touchette and Burkholder, 2000). Ulva sp. was present at low frequency in 1970, and Gracilaria dura, Ulvaria obscura and Ulva sp. populations developed in the early 2000s (Fig. 6). The increase in the populations of these macroalgae and their subsequent decomposition may have resulted in anoxic conditions unfavorable for aquatic angiosperms (Coffaro and Bocci, 1997). A qualitative shift from the pristine aquatic angiosperm community to macroalgal blooms in Mediterranean lagoons until the mid-1970s has been demonstrated, with aquatic angiosperm populations decreasing in nutrient-rich waters (Viaroli et al., 2008). Several shallow lagoons were covered with extensive meadows of Ruppia and/or Zostera in the past, but increases in nutrient inputs in recent decades have led to the rapid development 
523

of Ulva sp. and Gracilaria sp. blooms and the displacement of aquatic angiosperms (Sfriso

524 and Marcomini, 1996; Bombelli and Lenzi, 1996; Viaroli et al., 2006; Sfriso and Facca, 525 2007).

During the summer of 2007, a dystrophic crisis occurred in Biguglia lagoon, with the

527 recording of high chlorophyll $a$ concentrations (up to $200 \mu \mathrm{g} . \mathrm{L}^{-1}$ ). It was difficult to identify

528 the trigger elements, but this dystrophic crisis was associated with massive development of

529 the potentially toxic cyanobacteria Anabaenopsis circularis (IFREMER data; Fig. 6). The

530 Anabaenopsis circularis (freshwater species) bloom was a direct consequence of the decrease

531 in salinity (Pulina et al. 2011), which was associated with high nutrient concentrations. By

532 cascading effect, cyanobacteria bloom and salinity decrease concomitant with temperature

533 increase in summer engendered the accumulation of organic matter by phytoplankton and the

534 death of macroalgae in the Biguglia lagoon, causing strong anoxia. The capacity of aquatic

535 angiosperms to retain nitrogen is dependent on an internal control system that keeps the

536 nitrogen cycle balanced and counteracts shifts in the community towards macroalgae or

537 phytoplankton (Valiela et al., 1997). When nutrient loads increase, massive macroalgal

538 development can induce physical and chemical changes in the water. Floating mats of algae

539 decrease light penetration into the water, leading to the formation of layers of water with

540 different properties, with oxygen-rich water towards the surface and anoxic conditions

541 towards the bottom (Souchu et al., 1998; Brush and Nixon, 2003). Sulfide and nutrients

542 released into the water act as a stressor for aquatic angiosperm and macroalgae (Azzoni et al.,

543 2001). The last phase of the transition from healthy to stressed ecosystems is dominated by

544 phytoplankton, as observed during the dystrophic crisis of the summer of 2007.

545 Phytoplankton levels are often high in heavily degraded lagoons (Sfriso and Facca, 2007) and

546 play a crucial role in controlling the flows of matter and energy in coastal environments (Bec

547 et al., 2011). However, the paradigm that increasing nutrient load causes an irreversible 
548 transition from aquatic angiosperms to macroalgae or phytoplankton communities can now be

549 called into question, because this paradigm is not well-supported by quantitative theories or 550 models (Nixon et al., 2001). However, after 2007, the chlorophyll $a$ concentrations measured 551 in Biguglia lagoon in the summer were similar to those in other Mediterranean lagoons 552 (Souchu et al., 2010; Giordani et al., 2009), or coastal embayments (Saeck et al., 2013; Lie et 553 al., 2011).

554 Recent deteriorations in water quality led the managers of the Biguglia lagoon nature 555 reserve to take various remedial measures, such as periodically opening up the current 556 channel of communication with the sea by mechanical means (significant salt water input; 557 particularly during 2012, with an exceptional increase in the salinity of the lagoon) and 558 cleaning the Fossone Canal from 2009 to 2012 (significant freshwater inputs), to decrease the 559 confinement of the southern basin (Département de la Haute-Corse, 2013). Substantial efforts 560 have also been made to improve sewage treatment in the watershed under the Schéma 561 d'Aménagement et de Gestion des Eaux (SAGE; Département de la Haute-Corse, 2012). After 2007, the abundance of aquatic angiosperms increased in this lagoon (Fig. 6), particularly for 563 Ruppia cirrhosa across the lagoon, and Stuckenia pectinata in the south, with a resurgence of 564 Najas marina in the southern basin of the lagoon (low salinity). The macroalgae Gracilaria bursa-pastoris and Gracilaria dura appeared during this period, but only in a small area (Fig. 6). The point at which a system shifts from one state to another depends on the external 567 nutrient load and the water exchange time (Dahlgren and Kautsky, 2004). Primary producer 568 succession is often favored by hydrological and hydrodynamic conditions, such as currents 569 and flushing, which disperse the phytoplankton community (Flindt et al., 1997). In the system 570 studied here, such hydrological management measures improved the quality of the water 571 column, favoring the development of aquatic angiosperms over a relatively short period of 572 time (4-5 years). Biguglia lagoon seems to be very resilient, and the shifts observed may be 
573 reversible. Improvements in wastewater treatment in the watershed, to decrease nutrient

574 inputs, will also be essential, to prolong the effects of these management efforts and to allow 575 the system to recover.

In conclusion, Biguglia lagoon remains vulnerable to sporadic shifts, due to several

577 factors: (i) hydrological management of the watershed and the communication channel with

578 the sea, with effects on salinity, (ii) nutrient inputs from the watershed, (iii) natural climatic

579 phenomena (rainfall, wind) or climate change (Lloret et al., 2008). As evidence of ecosystem

580 degradation accumulates, it is often difficult to distinguish between natural variations of the

581 state of the ecosystem and human-induced changes. We used long-term (two hundred years)

582 historical data to determine the pattern of change in human activities on the watershed of

583 Biguglia lagoon, including the many hydrological developments affecting salinity and, thus,

584 the distribution of aquatic angiosperms. Many changes in salinity have occurred in Biguglia

585 lagoon, and there is still a steep spatial gradient of salinity, but aquatic angiosperms have

586 adapted to cope with such abrupt changes. Over the last 40 years, human activities have

587 profoundly altered the Biguglia lagoon, with changes in the aquatic vegetation, from a

588 predominance of aquatic angiosperms to macroalgae and phytoplankton during a dystrophic

589 crisis in 2007. The observed shift in the community suggests that Biguglia lagoon is resilient

590 and that the transition may be reversible. The restored communities closely resemble the

591 pristine communities. The disturbances at this lagoon do not, therefore, seem to have

592 exceeded the threshold beyond which lagoons cannot recover. Actions aiming to restore the

593 ecosystem of this lagoon should take this resilience into account, but should also consider the

594 desired ecosystem services.

595

596

597 Acknowledgments 
This study received financial support from the national water agency (Rhône599 Méditerranée-Corse) and from the European ZOUMGEST program "ZOne UMide: sistemi GESTionali per integrare le attività antropiche e la tutela della natura" between France and

601

Italy and the Département de la Haute-Corse. We thank our colleagues from the Département de la Haute-Corse (Réserve Naturelle de l'Etang de Biguglia) for their help during field investigations. This paper uses data from the Lagoon Monitoring Network (Réseau de Suivi Lagunaire) funded by Agence de l'Eau Rhône Méditerranée Corse, Région LanguedocRoussillon and IFREMER. The authors thank the anonymous reviewers who helped us to improve the quality of the manuscript.

\section{References}

Albitreccia, A., 1942. Le plan terrier de la Corse au XVIIIème siècle. Presses Universitaires de France, Paris, France.

Aminot, A., Kérouel, R., 2004. Hydrologie des écosystèmes marins : paramètres et analyses. IFREMER, Méthodes d'analyse en milieu marin, France.

Andral, B., Orsoni, V., Sauzade, D., 2007. Directive Cadre Eau - Mise en œuvre du Contrôle de Surveillance - résultat de la campagne 2006 - District Corse. Ifremer/Agence de 1'eau, France.

Azzoni, R., Giordani, G., Bartoli, M., Welsh, D.T., Viaroli, P., 2001. Iron, sulphur and phosphorus cycling in the rhyzosphere sediments of a eutrophic Ruppia cirrhosa meadow of the Valle Smarlacca (Italy). J. Sea Res. 45, 15-26.

Barnes, R.S.K., 1980. Coastal Lagoons. In: Cambridge Studies in Modern Biology 1. Cambridge University Press, Cambridge. 
622 Battaglia, B., 1959. Final resolution of the symposium on the classification of brackish waters. Archo Oceanogr. Limnol. 11, 243-248.

624 Bec, B., Collos, Y., Souchu, P., Vaquer, A., Lautier, J., Fiandrino, A., Benau, L., Orsoni, V., 625 Laugier, T., 2011. Distribution of picophytoplankton and nanophytoplankton along an 626 anthropogenic eutrophication gradient in French Mediterranean coastal lagoons. Aquat. 627 Microb. Ecol. 63, 29-45.

628 Bird, E.C.F., 1994. Physical setting and geomorphology of coastal lagoons. In Kjerfve, B. (Ed.). Coastal lagoon processes. Elsevier Oceanography Series 60, Amsterdam, pp 9-30.

Bombelli, V., Lenzi, M., 1996. Italy-The Orbetello lagoon and the Tuscany coast. In Marine Benthic Vegetation. Recent Changes and the Effects of Eutrophication, Schramm W., Nienhuis P.H. (eds). Springer: New York, pp 331-337.

Brush, M.J., Nixon, S.W., 2003. Biomass layering and metabolism in mats of the macroalga Ulva lactuca L. Estuaries 26, 916-926.

Burelli, F., Ecrement, F., Frisoni, G.F., Guelorget, O., Ximenes, M.C., 1979. - Etude des écosystèmes de Biguglia, Diana et Urbino. Rapport SOMIVAC-GTGREF, France.

637 Caratini, R., 1995. Histoire du peuple Corse. Criterion, Paris, France.

638 Carpenter, S., Walker, B., Anderies, MJ., Abel, N., 2001. From metaphor to measurement: 639 resilience of what to what? Ecosystems 4, 765-781.

640 Charpentier, A., Grillas, P., Lescuyer, F., Coulet, E., Auby, I., 2005. Spatiotemporal dynamics 641 of a Zostera noltii-dominated community over a period of fluctuating salinity in a shallow 642 lagoon, Southern France. Estuar. Coast. Shelf Sci. 64, 307-315.

643 Chauvelon, P., Tournoud, M.G., Sandoz, A., 2003. Integrated hydrological modelling of a 644 managed coastal Mediterranean wetland (Rhone delta, France): initial calibration. Hydrol. $645 \quad$ Earth Sci. 7(1), 123-131. 
Clewell, A.F., Aronson, J., 2007. Ecological Restoration: Principles, Values, and Structure of an Emerging Profession. Island Press, Washington, DC.

Cloern, J.E., 2001. Our evolving conceptual model of the coastal eutrophication problem. Mar. Ecol. Prog. Ser. 210, 235-265.

Cloern, J.E., Jassby, A.D., 2012. Drivers of change in estuarine-coastal ecosystems: Discoveries from four decades of study in San Francisco Bay. Rev. Geophys. 50, pRG4001.

Coffaro, G., Bocci, M., 1997. Resources competition between Ulva rigida and Zostera marina: a quantitative approach applied to the Lagoon of Venice. Ecol. Mod. 102(1), 8195.

Collie, J.S., Richardson, C., Steele, J.M., 2004. Regime shifts: can ecological theory illuminate the mechanisms? Prog. Oceano. 60, 281-302.

Corvol, A., 1999. Les sources de l'histoire de l'environnement. Le XIXè siècle. L'Harmattan Édition, Paris, France.

Dahlgren, S., Kautsky, L., 2004. Can different vegetative states in shallow coastal bays of the Baltic Sea be linked to internal nutrient levels and external nutrient loads? Hydrobiologia $514,249-258$.

Day, J.W., Psuty, N.P., Pérez, B.C., 2000. The role of pulsing events in the functioning of coastal barriers and wetlands: implications for human impact, management and the response to sea level rise. In: Weinstein, M.P., Kreeger, D.A., (Eds.), Concepts and Controversies in Tidal Marsh Ecology. Kluwer Academic Publishing, Dordrecht, pp 633661.

De Casabianca, M.L., Kiener, A., Huve, H., 1973. Biotopes et biocénoses des étangs saumâtres corses : Biguglia, Diana, Urbino, Palo. Vie et Milieu 23, 187-227. 
De Jonge, V.N., Elliott, M., Orive, E., 2002. Causes, historical development, effects and future challenges of a common environmental problem: eutrophication. Hydrobiologia 475/476, 1-19.

Département de la Haute-Corse, 2012. Plan d'aménagement et de gestion durable: SAGE de l'étang de Biguglia. Conseil Général de la Haute-Corse, Corse, France.

Département de la Haute-Corse, 2013. Plan de gestion 2014-2018 de la réserve naturelle de l'étang de Biguglia. Conseil Général de la Haute-Corse, Corse, France.

De Wit, R., Stal, L.J., Lomstein, B.A., Herbert, R., van Gemerden, H, Viaroli, P., Cecherelli, V.U., Rodriguez-Valera, F., Bartoli, M., Giordani, G., Azzoni, R., Schaub, B., Welsh, D.T., Donnely, A., Cifuentes, A., Anton, J., Finster, K., Nielsen, L.B., Underlien Pedersen, A.G., Neubauer, A.T., Colangelo, M.A., Heijs, S.K., 2001. ROBUST: The ROle of BUffering capacities in STabilising coastal lagoon ecosystems. Cont. Shelf Res. 21, 20212041.

Dowing, J.A., 2014. Limnology and oceanography: two estranged twins reuniting by global change. Inland Waters 4, 215-232.

Duarte, C.M., 1995. Submerged aquatic vegetation in relation to different nutrient regimes. Ophelia 41, 87-112.

Duarte, C.M., Martinez, R., Barron, C., 2002. Biomass, production and rhizome growth near the northern limit of seagrass (Zostera marina) distribution. Aquat. Bot. 72, 183-189.

Elliot, M., Durbon, D., Hemingway, K.L., Apitz, S.E., 2007. Estuarine, coastal and marine ecosystem restoration: Confusing management and science - A revision of concepts. Estuar. Coast. Shelf Sci. 74, 349-366.

Facca, C., Ceoldo S., Pellegrino, N., Sfriso A., 2014. Natural recovery and planned intervention in coastal wetlands: Venice Lagoon (Northern Adriatic Sea, Italy) as a case study. Scientific World J. 968618. 
695 Ferreira, J.G., Andersen, J.H., Borja, A., Bricker, S.B., Camp, J., Cardoso da Silva, M., 696 Garcés, E., Heiskanen, A.S., Humborg, C., Ignatiades, L., Lancelot, C., Menesguen, A., 697 Tett, P., Hoepffner, N., Claussen, U., 2011. Overview of eutrophication indicators to assess 698 environmental status within the European Marine Strategy Framework Directive. Estuar. 699 Coast. Shelf Sci. 93, 117-131.

700 Fisher, T.R., Peele, E.R., Ammerman, J.W., Harding, Jr. L.W., 1992. Nutrient limitation of 701 phytoplankton in Chesapeake Bay. Mar. Ecol. Prog. Ser. 82, 51-63.

702 Flindt, M.R., Salomonsen, J., Carrer, M., Bocci, M., Kamp-Nielsen, L., 1997. Loss, growth 703 Ecol. Evol. Syst. 35, 557-581.

Folke, C., Carpenter, S., Walker, B., Scheffer, M., Chapin, T., Rockström, J., 2010. Resilience thinking: integrating resilience, adaptability and transformability. Ecol. Soc. 15(4), 20.

Fong, P., Kennison R.L., 2010. Phase shift, alternative stable states, and the status of Southern California lagoons. In: Kennish M.J., Peral H.W. (eds) Coastal lagoons: critical habitats of environmental change, vol 164, CRC, New York, pp 227-251.

Frisoni, G.F., Dutrieux, E., 1992. L'étang de Biguglia - Diagnostic écologique 1991-1992. and phytoplankton communities in a Mediterranean coastal lagoon. Part I: How to promote dinoflagellate dominance? Ma. Poll. Bull. 104, 139-152. 
Garrido, M., Lafabrie, C., Torre, F., Fernandez, C., Pasqualini, V., 2013. Resilience and stability of Cymodocea nodosa seagrass meadows over the last four decades in a Mediterranean lagoon. Estuar. Coast. Shelf Sci. 130, 89-98.

Giordani, G., Zaldívar, J. M., Viaroli, P., 2009. Simple tools for assessing water quality and trophic status in transitional water ecosystems. Ecol. Indic. 9(5), 982-991.

Handley, R.J., Davy, A.J., 2002. Seedling root establishment may limit Najas marina L. to sediments of low cohesive strength. Aquat. Bot. 73, 129-136.

Hauxwell, J, Valiela I., 2004. Effects of nutrient loading on shallow seagrass-dominated coastal systems: patterns and processes. In Estuarine Nutrient Cycling: The Influence of Primary Producers, Nielsen, S.L, Banta, G.T, Pedersen, M.F. (eds). Kluwer Academic Publishers: Dordrecht, The Netherlands; 59-92.

Hemminga, M.A., Duarte, C.M., 2000. Seagrass Ecology. Cambridge University Press.

Jaujou, C., 1954. La lutte antipaludique en Corse. Bull. Organisme mondial santé, 11, 635677.

Jennerjahn, T.C., Mitchell, S.B., 2013. Pressures, stresses, shocks and trends in estuarine ecosystems - An introduction and synthesis. Estuar. Coast. Shelf Sci. 130, 1-8.

Kemp, W.M., Boynton, W.R., Adolf, J.E., Boesch, D.F., Boicourt, W.C., Brush, G., Cornwell, J.C., Fisher, T.R., Glibert, P.M., Hagy, J.D., Harding, L.W., Houde, E.D., Kimmel, D.G., Miller, W.D., Newell, R.I.E., Roman, M.R., Smith, E.M., Stevenson, J.C., 2005. Eutrophication of Chesapeake Bay: historical trends and ecological interactions. Mar. Ecol. Prog. Ser. 303, 1-29.

Kjerfve B., 1994. Coastal Lagoon Processes. Elsevier, Oceanography Series 60, Amsterdam. Letteron, C., 1923. Causerie sur l'étang de Biguglia, Bull. Société Sci. Histor. Nat. Corse, France, 23, 45-61. 
Lie, A.A.Y., Wong, C.K., Lam, J.Y.C, Liu, J.H., Yung, Y.K., 2011. Changes in the nutrient ratios and phytoplankton community after declines in nutrient concentrations in a semienclosed bay in Hong Kong. Mar. Environ. Res. 71(3), 178-188.

Lloret, J., Marin, A., Marin-Guirao, L., 2008. Is coastal lagoon eutrophication likely to be aggravated by global climate change? Estuar. Coast. Shelf Sci. 78, 403-412.

Marzano, C.N., Liaci, L.S., Fianchini, A., Gravina, F., Mercurio, M., Corriero, G., 2003. Distribution, persistence and change in the macrobenthos of the lagoon of Lesina (Apulia, southern Adriatic Sea). Oceanol. Acta 26, 57-66.

Menéndez, M., 2002. Net production of Ruppia cirrhosa in Ebro Delta. Aquat. Bot. 73, 107113.

Menéndez, M., Comin, F.A., 1989. Seasonal patterns of biomass variation of Ruppia cirrhosa Petagna Grande and Potamogeton pectinatus L. in a coastal lagoon. Scient. Mar. 53, 633638.

Mouillot, D., Titeux, A., Migon, C., Sandroni, V., Frodello, J.P., Viale, D., 2000. Anthropogenic influences on a Mediterranean nature reserve: modelling and forecasting. Environ Mod. Assess. 5, 185-192.

Nienhuis, P.H., 1992. Ecology of coastal lagoons in The Netherlands (Veerse Meer and Grevelingen). Vie Milieu 42, 59-72.

Neveux, J., Lantoine, F., 1993. Spectrofluorimetric assay of chlorophylls and phaeopigments using the least squares approximation technique. Deep-Sea Res. 40, 1747-1765.

Nixon, S.W., 1995. Coastal marine eutrophication: a definition, social causes and future concerns. Ophelia 41, 199-219.

Nixon, SW, Buckley, BA, Granger, SL, Bintz, J. 2001. Responses of very shallow marine ecosystems to nutrient enrichments. Hum. Ecol. Risk Assess. 7, 1457-1481. 
768 Orfanidis, S., Reizopoulou, S., Basset, A., 2008a. Transitional states in transitional waters 769 (editorial). Aquat. Cons: Mar. Fresh. Ecosyst. 18, S1-S3.

770 Orfanidis, S., Pinna, M., Sabetta, L., Stamatis, N., Nakou, K., 2008b. Variation of structural 771 and functional metrics in macrophyte communities within two habitats of eastern 772 Mediterranean coastal lagoons: natural vs. anthropogenic effects. Aquat. Cons: Mar. Fresh. 773 Ecosyst. 18, S45-S61.

774 Orsoni, V., Souchu, P., Sauzade, D., 2001. Caractérisation de l'état d'eutrophisation des trois 775 principaux étangs corses (Biguglia, Diana et Urbino), et proposition de renforcement et 776 leur surveillance. Rapp. Ifremer, France.

777 Pasqualini, V., Pergent-Martini, C., Fernandez, C., Ferrat, L., Tomaszewski, J., Pergent, G., 778 2006. Wetland monitoring: aquatic plant changes in two Corsican coastal lagoons (Western 779 Mediterranean Sea). Aquat. Cons: Mar. Fresh. Ecosyst. 16: 43-60.

780 Pasqualini, V., Pergent-Martini, C., Fernandez, C., Pergent, G., 1997. The use of airborne 781 remote sensing for benthic cartography: advantages and reliability. Int. J. Rem. Sens. 782 18(5), 1167-1177.

783 Pergent, G., Pasqualini, V., Pergent-Martini, C., Ferrat, L., Fernandez, C., 2006. Variability of 784 Ruppia cirrhosa in two coastal lagoons with differing with differing anthropogenic 785 stresses. Bot. Mar. 49, 103-110.

786 Pergent-Martini, C., Pasqualini, V., Ferrat, L., Pergent, G., Fernandez, C., 2005. Seasonal 787 dynamics of Zostera noltii Hornem. in two Mediterranean lagoons. Hydrobiologia 543, 233-243.

789 Pulina, S., Padedda B.M., Sechi N., Lugliè A., 2011. The dominance of cyanobacteria in 790 Mediterranean hypereutrophic lagoons: a case study of Cabras Lagoon (Sardinia, Italy). 791 Scientia Marina 75(1), 111-120. 
792 Raimbault, P., Pouvesle, W., Diaz, F., Garcia, N., Sempere, R., 1999. Wet-oxidation and 793 automated colorimetry for simultaneous determination of organic carbon, nitrogen and 794 phosphorus dissolved in seawater. Mar. Chem. 66, 161-169.

795 Saeck, E.A., O'Brien, K.R., Weber, T.R., Burford, M.A., 2013. Changes to chronic nitrogen 796 loading from sewage discharges modify standing stocks of coastal phytoplankton. Mar. $797 \quad$ Poll. Bull. 71(1-2), 159-167.

798 San Roman Sanz, A., Mouillot, F, Ferrat, L., Fernandez, C., Istria, D., Pasqualini, V., 2013. 799 Long-term forest dynamic and land use abandonment in Mediterranean mountains 800 (Corsica, France). Ecol. Soc. 18(2), 38.

801 Scheffer, M., Carpenter, S., Foley, J. A., Folke C., Walker, B., 2001. Catastrophic shifts in 802 ecosystems. Nature 413, 591-596.

803 Schramm, W., 1999. Factors influencing seaweed responses to eutrophication: some results 804 from EU-project EUMAC. J. Appl. Phycol. 11, 69-78.

Schröder, A, Persson, L, De Roos, AM. 2005. Direct experimental evidence for alternative 806 stable states: a review. Oikos 110: 3-19.

Sfriso, A, Birkemeyer, T, Ghetti, PF. 2001. Benthic macrofauna changes in areas of Venice 808 lagoon populated by seagrasses or seaweeds. Mar. Environ. Res. 52, 323-349.

Sfriso, A, Facca, C, Ghetti, PF. 2003. Temporal and spatial changes of macroalgae and phytoplankton in a Mediterranean coastal area: the Venice lagoon as a case study. Mar. Environ. Res. (56)5, 617-636.

812 Sfriso, A., Facca, C., 2007. Distribution and production of macrophytes and phytoplankton in 813 the lagoon of Venice: comparison of actual and past situation. Hydrobiologia 577, 71-85.

814 Sfriso, A, Marcomini, A., 1996. Decline of Ulva growth in the lagoon of Venice. Biores. 815 Technol. 58, 299-307. 
Souchu, P., Bec, B., Smith, V.H., Laugier, T., Fiandrino, A., Benau, L., Orsoni, V., Collos, Y., Vaquer, A., 2010. Patterns in nutrient limitation and chlorophyll $a$ along an anthropogenic eutrophication gradient in French Mediterranean coastal lagoons. Can. J. Fish. Aquat. Sci. 67, 743-753.

Souchu, P., Gasc, A., Collos, Y., Vaquer, A., Tournier, H., Bibent, B., Deslous-Paoli, J.L., 1998. Biogeochemical aspects of bottom anoxia in a Mediterranean lagoon (Thau, France). Mar. Ecol. Progr. Ser. 164, 135-146.

Steyaert, P., Barzman, M., Billaud, J.P., Brives, H., Hubert, B., Ollivier, G., Roche, B., 2007. The role of knowledge and research in facilitating social learning among stakeholders in natural resources management in the French Atlantic coastal wetlands. Environ. Sci. Pol. $10,537-550$.

Suding, K.N., Gross, K.L., Housemann, G.R., 2004. Alternative states and positive feedbacks in restoration ecology. Trends Ecol. Evol. 19: 46-53.

Tagliapietra, D., Ghirardini, A.V., 2006. Notes on coastal lagoon typology in the light of the EU Water Framework Directive: Italy as a case study. Aquat. Conserv. Mar. Freshwat. Ecosyst. 16, 457-467.

Touchette, B.W., Burkholder, J.M., 2000. Review of nitrogen and phosphorus metabolism in seagrasses. J. Exp. Mar. Biol. Ecol. 250, 133-167.

Touzeau, G., Grall, J., Clavier, J., Chauvaud, L., Jean, F, Leynaert, A., Ni Longphuiet, S., Amice, E., Amouroux, D. (2007) Spatial and temporal variability in benthic biogeochemical fluxes in the Thau lagoon associated with macrophytic and macrofaunal distribution. Estuar. Coast. Shelf Sci. 72: 432-447.

Valiela, I., McLelland, J., Hauxwell, J., Behr, P.J, Hersh, D., Foreman, K., 1997. Macroalgal blooms in shallow estuaries: controls and ecophysiological and ecosystem consequences. Limnol. Oceanogr. 42, 1105-1118. 
841 Verhoeven, J.T.A., 1979. The ecology of Ruppia-dominated communities in Western Europe.

842 I. Distribution of Ruppia representatives in relation to their autecology. Aquat. Bot 6, 197843268

844 Viaroli, P, Bartoli, M, Bondavalli, C, Christian, RR, Giordani, G, Naldi, M., 1996. 845 Macrophyte communities and their impact on benthic fluxes of oxygen, sulphide and 846 nutrients in shallow eutrophic environments. Hydrobiologia 329, 105-119.

847 Viaroli, P., Bartoli, M., Giordani, G., Naldi, M., Orfanidis, S., Zaldivar, J.M., 2008. 848 Community shifts, alternative stable states, biogeochemical controls and feedbacks in 849 eutrophic coastal lagoons: a brief overview. Aquat. Cons.: Mar. Fresh. Ecosys. 18, 105$850 \quad 117$.

851 Viaroli, P., Giordani, G., Bartoli, M., Naldi, M., Azzoni, R., Nizzoli, D., Ferrari, I., Zaldivar, 852 J.M., Bencivelli, S., Castaldelli, G., Fano, E.A., 2006. The Sacca di Goro lagoon and an 853 arm of the Po River. In The Handbook of Environmental Chemistry. Volume H: Estuaries, 854 Wangersky PJ (ed.). Springer-Verlag, pp 197-232.

855 Vidal, M., Morgui, J.A., Latasa, M., Romero, J., Camp, J., 1997. Factors controlling seasonal 856 variability of benthic ammonium release and oxygen uptake in Alfacs Bay (Ebro Delta, 857 NW Mediterranean). Hydrobiologia 350, 169-178. 
860 Fig. 1. Location of Biguglia lagoon (Corsica, France, Mediterranean Sea) and the stations 861 sampled.

862 Fig. 2. Spatiotemporal variations of subsurface salinity, temperature, nitrate, ammonium, 863 phosphate, total nitrogen, total phosphorus, and chlorophyll $a$ (chl a) concentrations, 864 registered during each of the summer months from 1999 to 2014 in Biguglia lagoon.

865 Fig. 3. Spatial distribution of macrophytes and bottom types in Biguglia lagoon in 2010.

866 Fig. 4. Monitoring of macrophyte dynamics at 15 sampling stations (S1 to S15) in Biguglia 867 lagoon between 1999 and 2014 (Ca: Chaetomorpha aerea; Cv: Cladophora vagabunda; Gd: 868 Gracilaria dura; Gg: Gracilaria gracilis; Gb: Gracilaria bursa-pastoris; Ns: Neosiphonia 869 sertularioides; Ui: Ulva instestinalis; Uo: Ulvaria obscura; Ur: Ulva rigida; nd: not determined; The values shown correspond to the percentage cover of the species concerned).

871 Fig. 5. Principal component analysis of water column, meteorological and macrophyte data for the 872 southern (station BIS) and northern (station BIN) basins of Biguglia lagoon in June 1999, 2003, 2009, 8732012 and 2014. Loadings of the 9 active variables (illustrative variables in gray) on the plane defined 874 by PC1 and PC2 (a). Location of stations centroids by year on the plane PC1-PC2 (b). The numbers 875 following station names correspond to the sampling year (ex: BIS:09= Biguglia south, year 2009).

876 Fig. 6. Conceptual representation of the succession of aquatic vegetation with eutrophication 877 and salinity variations in Biguglia lagoon. 


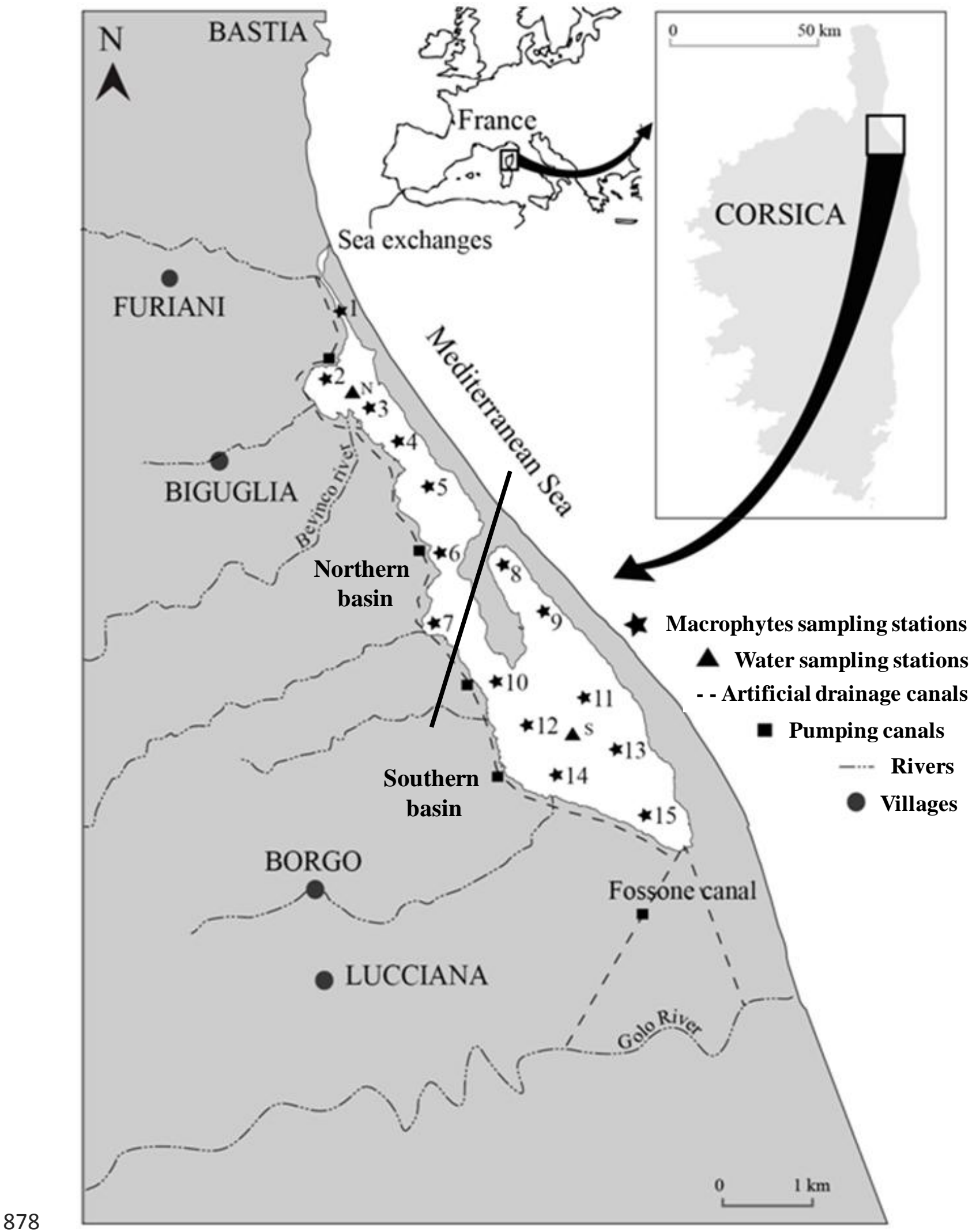

$879 \quad$ Fig. 1. 

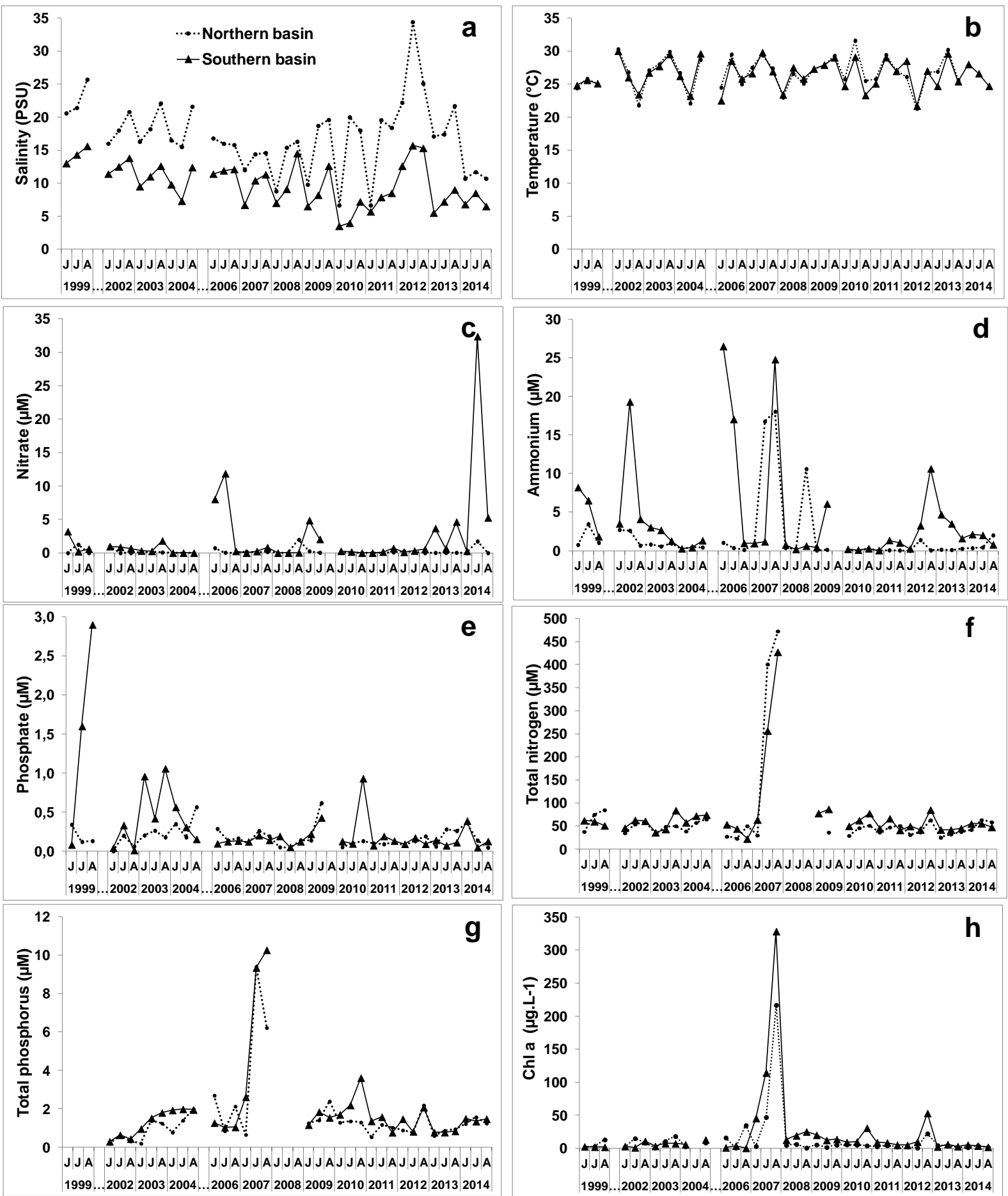

Fig. 2. 

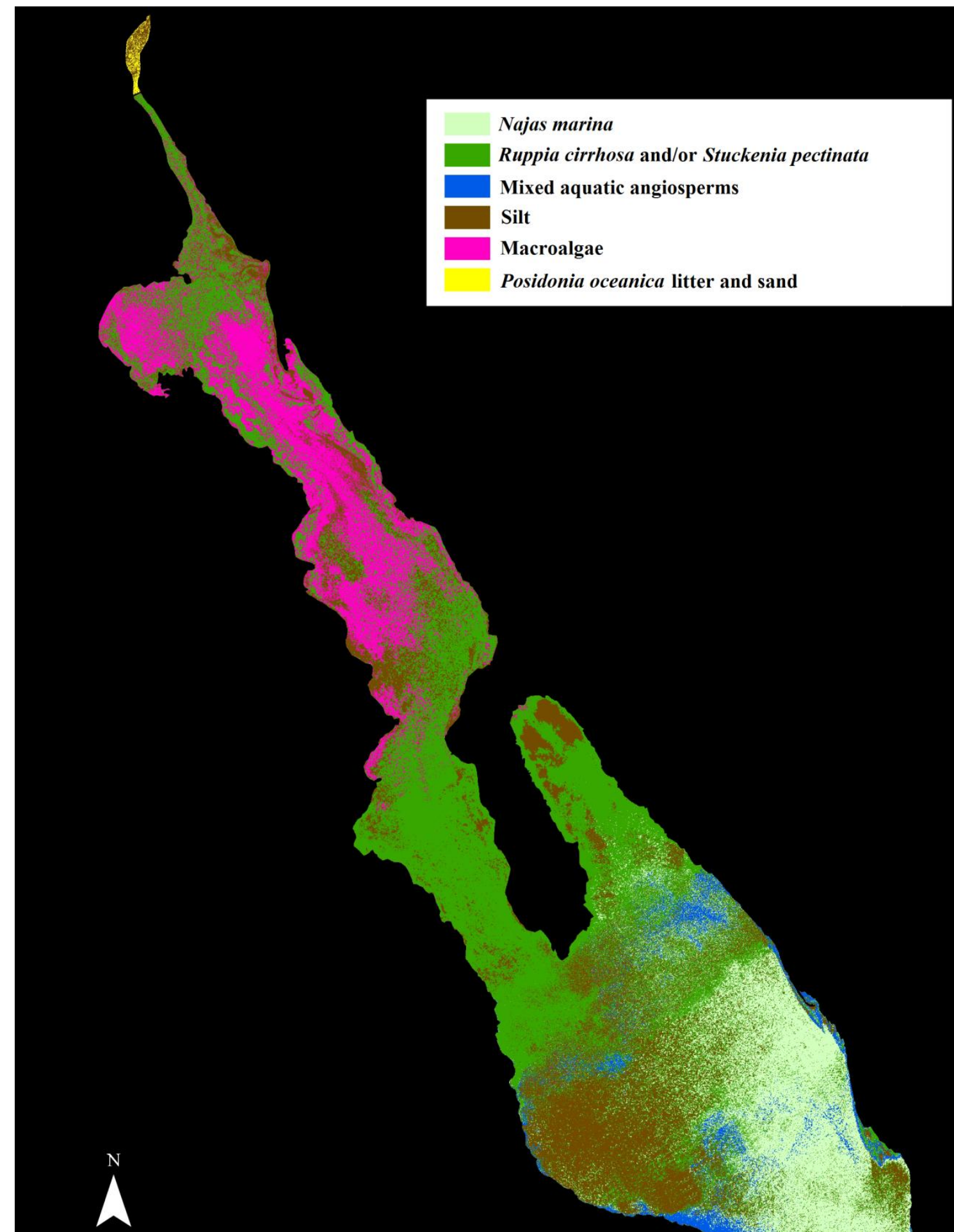

\section{$0.5 \mathrm{Km}$}

Posidonia oceanica litter and sand

886 Fig. 3. 



Fig. 4. 


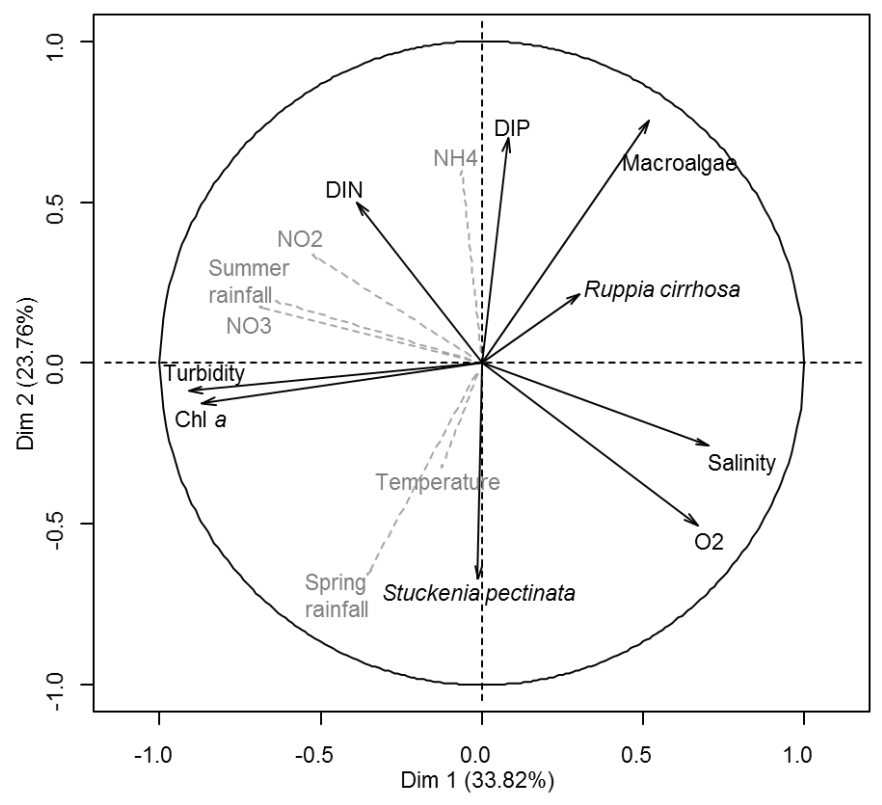

890

891 b

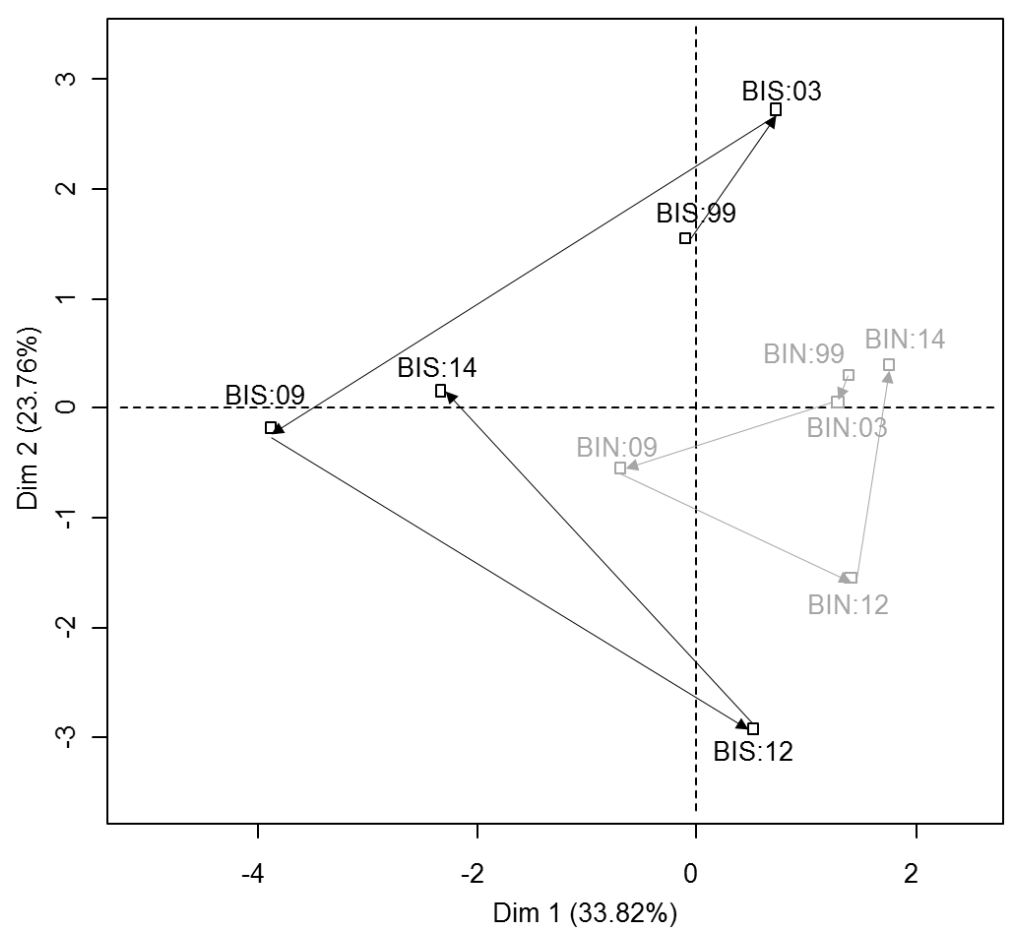

892

893 Fig. 5. 


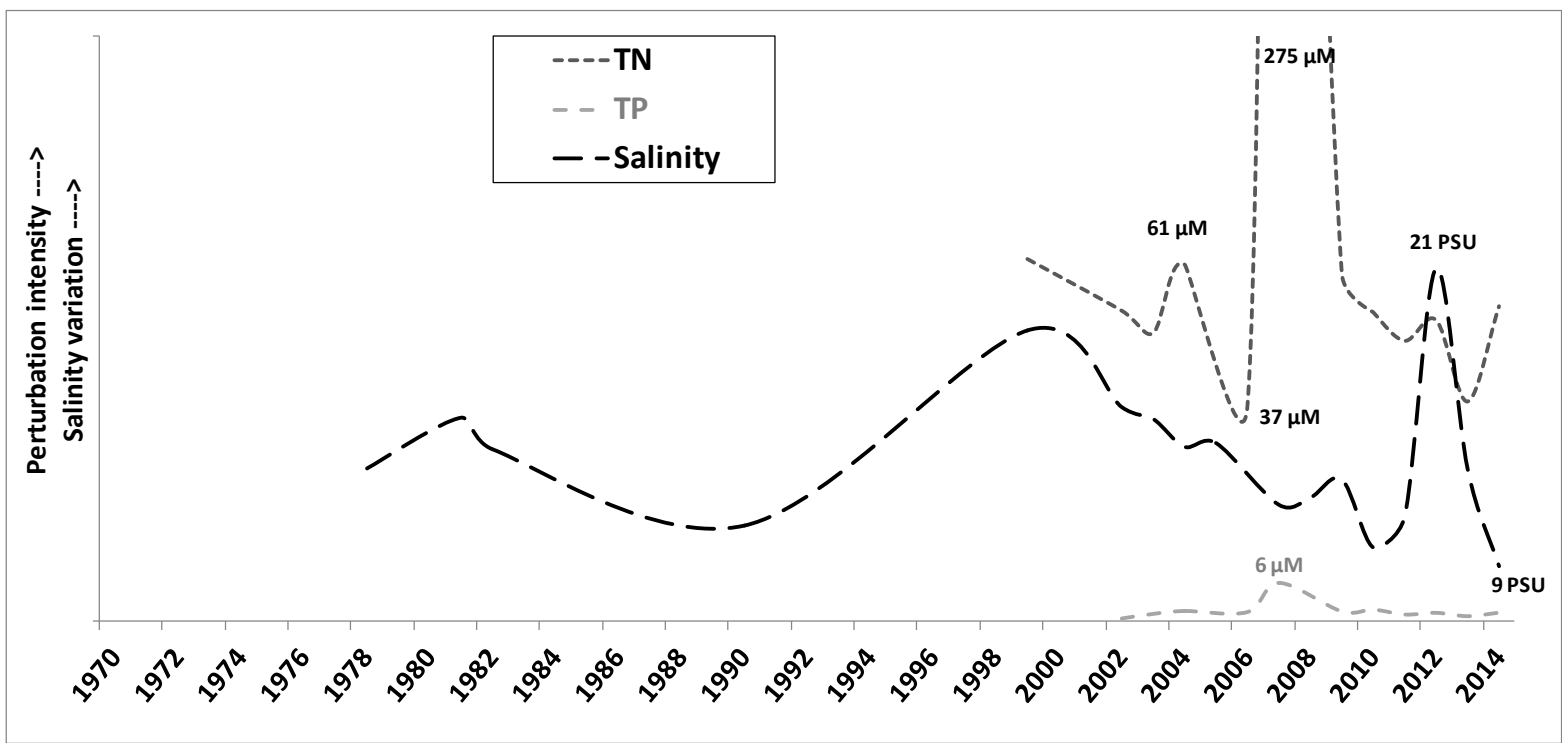

895

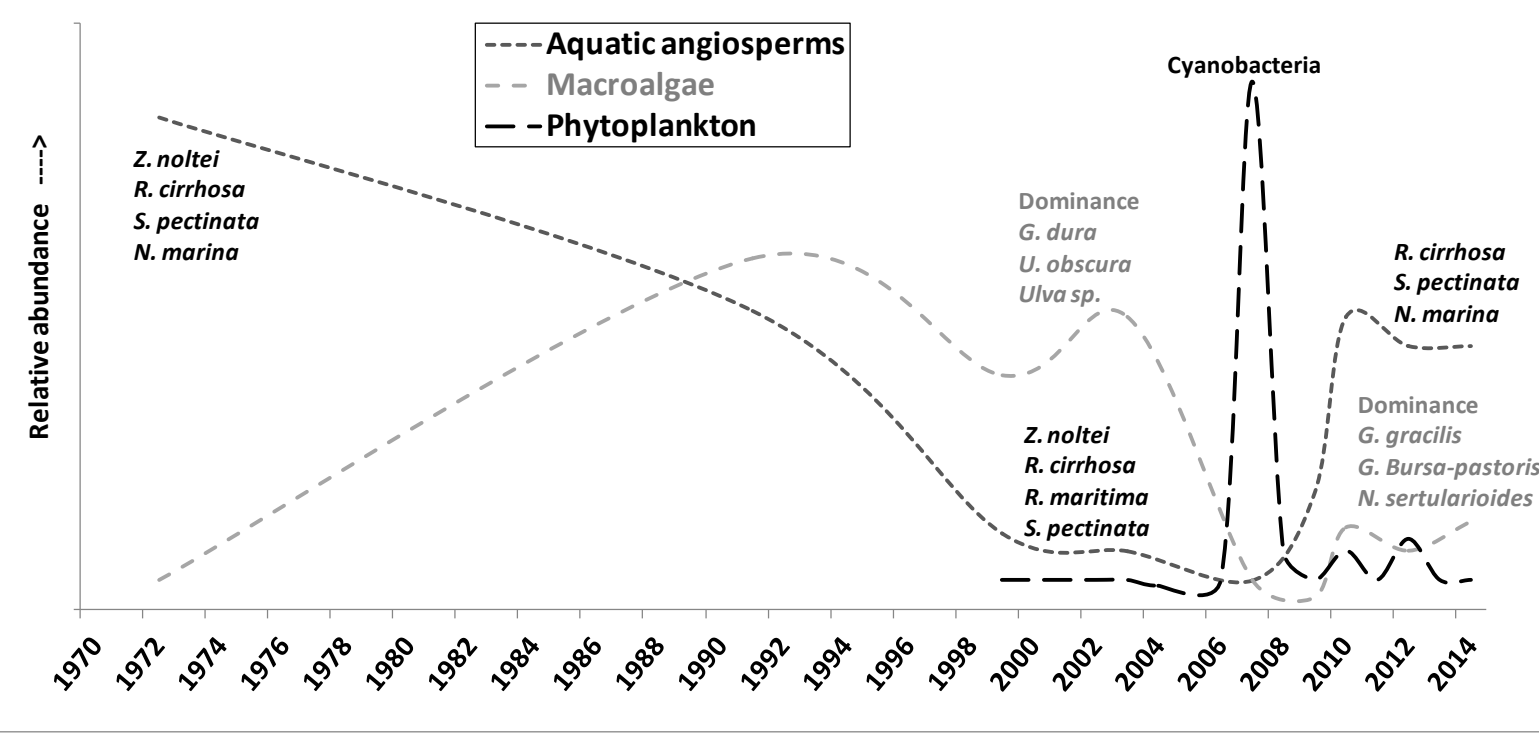

896 Fig. 6.

897

898

899

900 


\section{Table 1}

903 Historical changes in Biguglia lagoon in terms of the human population and major land uses

904 in the watershed from the $18^{\text {th }}$ century to the present day.

\begin{tabular}{rrrr}
\hline \multicolumn{4}{c}{ Human population } \\
\hline Year & 1800 & 1881 & 2011 \\
Number of inhabitants & 1290 & 1863 & 25663 \\
& & & \\
\hline Major land uses (\% of total land) \\
Year & 1774 & 1879 & $\mathbf{2 0 0 6}$ \\
Forests and Shrublands & 56 & 12 & 42 \\
Farmland & 40 & 84 & 40 \\
Urban areas & 4 & 4 & 17
\end{tabular}


Table 2

907 Kruskal-Wallis one-way analysis of variance on ranks for the environmental data for Biguglia lagoon.

\begin{tabular}{|c|c|c|c|c|c|c|c|c|c|c|}
\hline \multicolumn{11}{|l|}{ Difference between years } \\
\hline Parameters & Salinity & Temperature & Turbidity & $\begin{array}{l}\text { Dissolved } \\
\text { oxygen }\end{array}$ & Nitrates & Ammonium & Phosphates & Total nitrogen & $\begin{array}{l}\text { Total } \\
\text { phosphorus }\end{array}$ & Chlorophyll $a$ \\
\hline \multicolumn{11}{|l|}{ Northern basin } \\
\hline Kruskal-Wallis: p-values (significant in bold) & 0.031 & 0.431 & 0.009 & 0.094 & 0.576 & 0.016 & 0.194 & 0.334 & 0.052 & 0.829 \\
\hline $\begin{array}{l}\text { Conover-Iman test: years different to } \\
\text { other years (lower values) }\end{array}$ & $\begin{array}{l}2007 \\
2014\end{array}$ & & 2003 & & & 2011 & & & & \\
\hline $\begin{array}{l}\text { Conover-Iman test: years different to } \\
\text { other years (higher values) }\end{array}$ & 2012 & & 2007 & & & $\begin{array}{l}1999 \\
2002 \\
2007\end{array}$ & & & & \\
\hline \multicolumn{11}{|l|}{ Southern basin } \\
\hline Kruskal-Wallis: $p$-values (significant in bold) & 0.008 & 0.855 & 0.006 & 0.692 & 0.016 & 0.055 & 0.212 & 0.070 & 0.002 & 0.004 \\
\hline $\begin{array}{l}\text { Conover-Iman test: years different to } \\
\text { other years (lower values) }\end{array}$ & 2010 & & 2003 & & 2004 & & & & $\begin{array}{l}2002 \\
2013\end{array}$ & $\begin{array}{l}1999 \\
2006\end{array}$ \\
\hline $\begin{array}{l}\text { Conover-Iman test: years different to } \\
\text { other years (higher values) }\end{array}$ & $\begin{array}{l}1999 \\
2012\end{array}$ & & 2007 & & $\begin{array}{l}2006 \\
2009 \\
2013 \\
2014\end{array}$ & & & & 2007 & 2007 \\
\hline
\end{tabular}


Table 3

911 Temporal changes in the aquatic angiosperm and macroalgae communities of Biguglia lagoon.

\begin{tabular}{|c|c|c|c|c|}
\hline $\begin{array}{l}\text { Year } \\
\text { References }\end{array}$ & $\begin{array}{c}\mathbf{1 9 7 2 / 1 9 7 3} \\
\text { De Casabianca et al., } 1973\end{array}$ & $\begin{array}{c}1991 \\
\text { Frisoni and Dutrieux, } 1992\end{array}$ & $\begin{array}{c}1999 \\
\text { Pasqualini et al., } 2006\end{array}$ & $\begin{array}{c}\mathbf{2 0 1 0} \\
\text { This study }\end{array}$ \\
\hline Aquatic angiosperms & $\begin{array}{l}\text { Zostera noltei } \\
\text { Ruppia cirrhosa } \\
\text { Stuckenia pectinata } \\
\text { Najas marina }\end{array}$ & $\begin{array}{l}\text { Ruppia maritima } \\
\text { Stuckenia pectinata }\end{array}$ & $\begin{array}{l}\text { Zostera noltei } \\
\text { Ruppia cirrhosa } \\
\text { Ruppia maritima } \\
\text { Stuckenia pectinata }\end{array}$ & $\begin{array}{l}\text { Ruppia cirrhosa } \\
\text { Stuckenia pectinata } \\
\text { Najas marina }\end{array}$ \\
\hline $\begin{array}{l}\text { Percentages of aquatic } \\
\text { angiosperms }\end{array}$ & 84 & 51 & 13 & 62 \\
\hline Main macroalgae & Ulva sp. & Ulva sp. & $\begin{array}{l}\text { Gracilaria sp. } \\
\text { Ulva } \mathrm{sp} .\end{array}$ & $\begin{array}{l}\text { Gracilaria sp } \\
\text { Ulva } \mathrm{sp} .\end{array}$ \\
\hline $\begin{array}{l}\text { Percentage or presence } \\
\text { of main macroalgae }\end{array}$ & $\begin{array}{l}\text { Weak presence } \\
\text { (not calculated) }\end{array}$ & 65 & 7 & 14 \\
\hline
\end{tabular}

